\title{
Aktivitas Peroksidase Mutan Pisang Kepok dengan Ethyl Methane Sulphonate (EMS) secara In Vitro ${ }^{1}$
}

\author{
Yulmira Yanti \\ Jurusan Hama dan Penyakit Tumbuhan, Fakultas Pertanian Universitas Andalas, Padang 25163 \\ Diterima 04-11-2009_Disetujui 19-05-2011
}

\begin{abstract}
The activity of peroxidase were observed in leave of banana clone Kepok resulting by treatments EMS. The phenotype of peroxidase was analyzed from the banana clones resulting the induced by EMS and without induction after inoculated with pathogen Banana Blood deases Bacterium (BBD). The objectives of research are know variation of activity and band pattern of peroxidase. Induced mutation treatments consist of control, $0.2 \%$ EMS for 1 and 3 hours, $0.5 \%$ for 1 and 3 hours, each treatments was provided five banana clones. The result showed that variant value and coefisien variant of peroxidase activity in leaf tissue of clone treated by EMS increased compare to the control. A variant control is 0.28 with coefisien variant is $29.92 \%$, while variant value of treatment is 8.45 with coefisien variant is $75.75 \%$. Appearance of peroxidase bands on clone resulting by EMS treatments were emerged four band pattern. The first and control band pattern has relative migration distance is 20 and 30, the second 15, 40 and 60, the third is 15,35 and 50 . There are four bands with different relative migration distance that indicated polymorphic.
\end{abstract}

Keywords: activity, EMS (Ethyl Methane Soulphonate), kepok banana, peroxidase

\section{PENDAHULUAN}

Pisang merupakan salah satu komoditi ekspor yang bernilai penting karena sebagai bahan untuk industri pisang olahan dan sebagai sumber pangan substitusi beras. Pisang memiliki beberapa keunggulan antara lain produktivitas, nilai gizi dan ragam genetiknya tinggi, adaptif pada ekosistem yang luas, biaya produksi rendah serta telah diterima secara luas oleh masyarakat. Berdasarkan data Badan Pusat Statistik tahun 1996-2006, produksi pisang Indonesia belum mencukupi kebutuhan konsumen dalam negeri. Hal ini disebabkan tingginya serangan hama dan penyakit pada tanaman pisang. Salah satu penyakit sistemik yang berbahaya adalah serangan penyakit darah bakteri Banana Blood deases Bacterium (BBD) yang disebabkan oleh bakteri Ralstonia solanacearum phytotipe IV (Fegan \& Prior 2005).

Saat ini induksi merupakan salah satu cara yang sering digunakan para peneliti sebagai usaha untuk memperoleh tanaman yang lebih tahan terhadap suatu penyakit. Keberhasilan induksi mutasi pada tiap-tiap jenis tanaman tergantung pada jenis mutagen, kosentrasi mutagen, lama perlakuan mutagen, umur dan organ yang diperlakukan. Mutagen kimia yang biasa dipakai pada berbagai tanaman antara lain Ethyl Methane Sulphonate (EMS), diethyl sulphonate dan sodium azide. Dari beberapa mutagen kimia yang telah dipergunakan tersebut EMS sering menghasilkan mutan yang bermanfaat. Jamaluddin (1995), telah melakukan penelitian pada pisang Mas dan pisang Rastali yang diperlakukan dengan EMS pada konsentrasi 0,5\% selama 2 jam secara in vitro telah mampu menghasilkan mutanmutan yang mempunyai karakter kapasitas pertumbuhan yang tinggi serta tahan terhadap penyakit layu Fusarium. Selanjutnya Yanti et al. (2008), melaporkan bahwa induksi dengan mutagen EMS 0,2-0,4\% selama 2-4 jam pada tunas pisang Raja Sereh menghasilkan jumlah tunas yang bervariasi serta tahan terhadap penyakit BBD. Menurut Micke (1996), bahwa induksi mutasi pada tanaman ditujukan untuk perbaikan sifat genetik, terutama untuk peningkatan produksi, ketahanan terhadap hama dan penyakit serta toleransi terhadap cekaman lingkungan.

Mutagen dapat menyebabkan perubahan DNA sehingga struktur gen mengalami perubahan pula, akibat yang ditimbulkan adalah 1) perubahan yang tidak dapat mengubah enzim/protein tetapi aktivitasnya berbeda, 2) perubahan DNA yang menyebabkan kegagalan mensintesis enzim/protein atau terbentuk alel resesif (Micke 1996; Silverio et al. 2007). Jika terjadi perubahan gen-gen yang berperan dalam pertahanan maka peluang untuk memperoleh mutan yang tahan terhadap suatu penyakit (Potdukhe 2004). Gen ketahanan hipersensitif yang dominan diekspresikan pada tanaman adalah gen penyandi enzim peroksidae dan polifenol peroksidase. Kedua enzim tersebut lebih umum berperan dalam mekanisme pertahanan terhadap penyakit sehingga aktivitasnya dijadikan sebagai induksi ketahanan (Saravanan et al. 2004). 
Enzim peroksidase merupakan salah satu enzim tanaman yang mempunyai hubungan dengan proses ketahanan. Untuk mengetahui kepekaan dan ketahanan tanaman terhadap serangan penyakit dipergunakan pendekatan mengenai pengaruh stres lingkungan terhadap proses fisiologi tanaman. Cekaman lingkungan dapat mempengaruhi aktivitas gen dan menentukan kapan, bagaimana dan berapa banyak suatu enzim/protein dapat diproduksi dalam organ atau jaringan tanaman (Imelda et al. 2001). Serangan penyakit, kerusakan mekanis dan populasi juga dapat mempengaruhi aktivitas gen tersebut yang berakibat juga terhadap sinstesis enzim (Rahayuningsih et al. 1989; Carusso et al. 2001).

Peroksidase memiliki beberapa isozim yang terdiri dari berbagai molekul aktif dengan struktur kimia yang berbeda disandikan oleh gen-gen pada lokus yang sama atau pada lokus yang berbeda yang mengkatalisis reaksi yang sama (Michael et al. 1983). Enzim peroksidase terdapat di vakuola atau ruang interseluler dan dinding sel dengan bobot molekul 44.000 Dalton, tersusun dari gugus prostetik hemin, $2 \mathrm{Ca}^{2+}, 308$ asam amino termasuk empat jembatan disulfida dalam satu rantai polipeptida yang membawa delapan rantai karbohidrat netral dan mempunyai struktur kuartener (Gaspar 1984). Enzim tersebut merupakan enzim oksidase yang paling tinggi intensitasnya di dalam jaringan luka atau sakit (Agrios 2005 ). Enzim ini mempunyai struktur kuartener yang terdapat di sitosol dan dinding sel.

Aktivitas enzim peroksidase punya korelasi positif yang terbatas pada tanaman dewasa, sedangkan pada tanaman muda korelasi tersebut kurang pasti atau tidak ada. Hasil penelitian menunjukkan bahwa aktivitas peroksidase dipengaruhi oleh faktor genetik dan faktor lingkungan (Ritawati 2001). Selanjutnya Agrios (2005), mengemukakan bahwa pada tanaman yang tahan terjadi peningkatan aktivitas peroksidase, sedangkan pada tanaman yang peka tidak ada perubahan atau bahkan turun dibandingkan dengan keadaan sehat. Arisoesilaningsih (1984), melaporkan bahwa tanaman yang Phaseolus vulgaris yang terserang rebah kecambah yang disebabkan oleh Rhizoctonia solani, ternyata mengalami peningkatan aktivitas peroksidase 9-16 kali lebih besar dibandingkan dengan jaringan tanaman sehat. Yuhermita (2002), melaporkan bahwa buah pada tanaman cabai rawit aktivitasnya dua kali lebih tinggi dibandingkan dengan cabai keriting dimana cabai rawit tergolong tahan sedangkan cabai keriting tergolong tidak tahan terhadap penyakit antraknosa. Hadi (2003), menyatakan bahwa tanaman karet yang tahan terhadap penyakit Corynespora aktivitas enzim peroksidase lebih tinggi dibandingkan dengan kontrol.

Beberapa penelitian telah dilakukan untuk melihat aktivitas peroksidase pada tanaman jagung, kedelai, sedangkan untuk mutan tanaman pisang Kepok belum dipelajari. Oleh karena itu, penelitian bertujuan mengetahui aktivitasi enzim peroksidase dan pola pita peroksidase hasil elektroforesis.

\section{BAHANDANMETODE}

Penelitian bersifat deskriptif. Induksi mutasi dengan Ethyl Methane Sulphonate (EMS) secara in vitro pada bonggol pisang Kepok yang telah bertunas yang diambil dari rumpun tanaman yang sehat. Pisang Kepok yang dimutasi secara in vitro adalah kultivar lokal asal Nagari Tabek Panjang Kecamatan Baso Kabupaten Agam. Bahan tanam yang digunakan sebagai eksplan adalah tunas yang berasal dari satu rumpun tanaman sehat dengan ukuran 20-40 cm. Di laboratorium tunas-tunas pisang tersebut disterilisasi dengan merendam ke dalam larutan kloroks $10 \%$ selama 10 menit, kloroks 5\% selama 5 menit, kloroks $1 \%$ selama 1 menit dan akhirnya dibilas dengan akuades steril sebanyak 3 kali. Tunas yang telah disterilisasi dikupas dengan menggunakan pisau skapel dalam Laminar Air Flow Cabinet (LAFC) sampai berukuran $3 \mathrm{~cm}^{3}$ untuk ditanam. Sebelum ditanam, tunas dibelah membujur menjadi empat bagian. Potongan tunas tersebut kemudian ditanam pada botol kultur diameter $5 \mathrm{~cm}$ yang telah berisi $\pm 20 \mathrm{ml}$ dalam medium Murashige Skoog (MS) yang telah ditambahkan 2 ppm Benzil Amino Purin (BAP) (Wisnubroto et al. 1994). Selanjutnya kultur diinkubasi pada ruang yang tidak ada cahaya matahari. Tunas yang muncul dari kultur pertama diperbanyak pada subkultur berikutnya.

Medium yang digunakan untuk induksi ketahanan bibit pisang adalah larutan mutagen EMS. Induksi mutasi dilakukan pada tahap tunas yang berumur kira-kira 2-3 minggu atau setelah subkultur dengan munculnya tunas baru. Tunas baru tersebut dipotong dan dikupas batang semunya dan ditinggalkan bagian meristemnya. Selanjutnya tunas tersebut dimasukkan ke dalam gelas piala volume (250 ml) yang telah berisi larutan mutagen EMS. Tunas yang telah diinduksi mutasi dan tanpa induksi (kontrol) dicuci dengan akuades steril sebanyak tiga kali kemudian dipindahkan ke medium MS yang ditambah dengan 2 ppm IAA, 4 ppm BAP dan $10 \mathrm{ml}$ air kelapa yang kemudian diinkubasi selama 10 hari dan selanjutnya diinkubasi di ruang yang tidak ada cahaya matahari langsung. 
Perlakuan terdiri dari a) kontrol, b) 0,2\% EMS selama 1 jam, c) 0,2\% EMS selama 3 jam, d) 0,5\% EMS selama1 jam dan e) 0,5\% EMS selama 3 jam masing-masing hasil perlakuan disediakan 5 bibit pisang yang telah diinokulasi dengan BBD. Penelitian ini dilakukan di laboratorium Fisiologi Tumbuhan dan kultur jaringan Jurusan Biologi, Fakultas Matematika dan Ilmu pengetahuan Alam, Universitas Andalas Padang, dan Laboratorium Pusat Antar Universitas, Institut Pertanian Bogor dari bulan Februari sampai Oktober 2007.

Sampel yang dipakai adalah daun muda dari bibit pisang Kepok yang berumur dua bulan setelah aklimatisasi dan satu minggu setelah diinokulasi dengan BBD. Ekstraksi enzim dilakukan menurut metode Kanazawa et al. 1981. Sampel daun segar dari bibit pisang Kepok di timbang sebanyak 1 gram kemudian dihancurkan dengan mortar setelah ditambahkan segera 2,5 ml 0,5 M larutan dapar kalium fosfat $\mathrm{pH} 7$ dan 0,1 g PVP. Campuran tersebut diambil ekstraknya dan disaring dengan dua lapis kain kassa, disentrifus dengan kecepatan $15.000 \mathrm{rpm} 15$ menit suhu $4^{\circ} \mathrm{C}$. Supernatan dipakai untuk analisis isozim dan pengukuran aktivitas enzim peroksidase. Pengukuran aktivitas enzim peroksidase menggunakan metode Bateman (1967). Ekstrak enzim sebanyak 0,2 $\mathrm{ml}$ dimasukkan ke dalam kuvet yang telah berisi $5 \mathrm{ml}$ larutan piragalol kemudian dikocok. Kuvet diletakkan pada spektrofotometer, diatur agar jarum menunjukkan absorban yang sama dengan angka nol pada panjang gelombang $420 \mathrm{~nm}$. Kuvet diangkat dan ditambah $0,5 \mathrm{ml} \mathrm{H}_{2} \mathrm{O}_{2} 1 \%$ kemudian dikocok dan diletakkan pada spektrofotometer. Perubahan absorban diamati setiap 5 detik, sampai tidak terjadi perubahan lagi. Analisis isozim dengan penyediaan gel dan analisa elektroforesis mengacu pada Sussiyanti (2000), terdiri dari a) running gel, b) running buffer, c) elektroforesis, d) pewarnaan dengan memodifikasi alat yang digunakan.

Pengamatan dilakukan terhadap aktivitas enzim peroksidase yang dihitung berdasarkan perubahan absorban persatuan waktu per gram jaringan, pola pita yang terbentuk pada setiap perlakuan per individu dengan membandingkan migrasi relatif.

Analisis data dilakukan terhadap fenotip peroksidase digambarkan dalam bentuk zimogram, berdasarkan pengukuran nilai migrasi relatif dari pita-pita yang terbentuk pada plat gel, nilai migrasi relatif dihitung berdasarkan rumus Mittal et al. (1997), yaitu: MR = (JMp1/JMp2) x 100 dimana: MR : Indeks migrasi relatif, JMp1 : Jarak migrasi pita pada gel (cm), JMp2 : Jarak migrasi warna penanda pada gel (cm).
Aktivitas enzim peroksidase pada daun bibit pisang Kepok hasil perlakuan EMS diolah dengan nilai rata-rata hitung $(\mathrm{X})=\sum \mathrm{f} \mathrm{xi} / \mathrm{n}, \operatorname{varian}\left(\mathrm{S}^{2}\right)=\mathrm{f}(\mathrm{x}-\mathrm{X} \text { rata-rata })^{2} / \mathrm{n}-1$ dan simpangan baku $(S)=\sqrt{ } S^{2}$

\section{HASIL DAN PEMBAHASAN}

Planlet pisang Kepok hasil perlakuan dengan mutagen EMS didapatkan tiga variasi morfologi. Variasi morfologi yang paling menonjol adalah perlakuan B dan D (EMS 0,2\% dan $0,5 \%$ selama 1 jam) warna daun kuning pucat; penampilan keriting; daun batang kuning pucat; daun kecil tidak beraturan diikuti oleh perlakuan C (EMS 0,2\% 3 jam) warna daun kuning pucat; penampilan keriting; daun batang kuning pucat; daun kecil-kecil dan tidak beraturan, perlakuan E (EMS 0,5\% 3 jam ) warna daun dan batang kuning pucat serta pada kontrol warna hijau; penampilan normal. Secara umum hampir semua warna daun planlet pada perlakuan dengan mutagen EMS kuning pucat.

Mutan bibit pisang Kepok dua bulan setelah aklimatisasi dan satu minggu setelah diinokulasi dengan BBD memperlihatkan morfologi berbeda dengan tanaman kontrol. Pada tanaman kontrol daun sudah mulai agak menguning pada daun muda dan patah pada pucuk berpilin serta patah yang menandakan bahwa tanaman tersebut telah terinfeksi oleh BBD.

Berdasarkan aktivitas enzim peroksidase pada daun bibit pisang Kepok diberi perlakuan dengan (EMS) pada Tabel 1.

Berdasarkan data yang ditampilkan pada Tabel 1 dapat dilihat bahwa nilai rata-rata aktivitas peroksidase jaringan daun bibit pisang Kepok diberi perlakuan dengan mutagen EMS lebih tinggi dibandingkan dengan kontrol yang tanpa perlakuan EMS. Nilai rata-rata aktivitas enzim peroksidase daun bibit pisang Kepok dengan perlakukan EMS yaitu 7,98 menit/g/jaringan, sedangkan nilai rata-rata pada kontrol yaitu 0,95 menit/g/jaringan. Ini menunjukkan bahwa dalam kelompok tanaman bibit yang diberi perlakuan EMS lebih banyak diperoleh individu yang memiliki aktivitas enzim peroksidase lebih tinggi dibandingkan tanaman yang tidak diberi perlakuan (kontrol). Nilai varian pada kontrol yaitu 0,28 dengan koefisien keragaman 29,92\%, sedangkan nilai varian pada perlakuan EMS 8,45 dengan koefisien keragaman

Tabel 1 Nilai rata-rata, simpangan baku dan koefisien keragaman aktivitas enzim peroksidase daun bibit pisang Kepok diberi perlakuan dengan EMS dan bibit tanpa perlakuan

\begin{tabular}{lccc}
\hline \multicolumn{1}{c}{ Tanaman bibit } & X & S $^{2}$ & CV \\
\hline Kontrol & 0,95 & 0,28 & $29,92 \%$ \\
Perlakuan EMS & 7,98 & 8,45 & $75,75 \%$ \\
\hline
\end{tabular}

Keterangan: $\mathrm{X}=$ Rata-rata; $\mathrm{S}^{2}=$ Varians; $\mathrm{CV}=$ Koefisien keragaman 
$75,75 \%$. Semakin meningkatnya koefisien keragaman dan nilai varian menunjukkan bahwa terjadi peningkatan variasi aktivitas enzim peroksidase pada mutan bibit pisang Kepok. Peningkatan variasi ini terjadi akibat telah terjadinya mutasi pada gen penyandi enzim peroksidase. Andini et al. (1993), melaporkan bahwa perlakuan dengan iradiasi sinar gamma pada substrat sagu yang mengandung Aspergillus oryzae dosis $0,25 \mathrm{kGy}$ dapat meningkatkan dan menurunkan nilai aktivitas enzim amylase. Induksi mutasi dengan mutagen kimia EMS dapat berpengaruh terhadap tingkat perubahan aktivitas enzim peroksidase (Sussiyanti 2000). Mutagen kimia dapat mengakibatkan perubahan berupa: 1) perubahan yang tidak mengubah jenis enzim tetapi mengakibatkan perubahan pada tingkat aktivitas enzimnya; 2) perubahan yang menyebabkan kegagalan mensintesis enzim/protein (Micke 1996).

Data yang ditampilkan pada Tabel 1 menunjukkan bahwa nilai varian dan koefisien keragaman aktivitas enzim peroksidase jaringan daun tanaman kontrol juga cukup tinggi yaitu 29,92\%, meskipun perbanyakan secara pisang melalui vegetatif. Tingginya nilai koefisien keragaman mungkin disebabkan karena tunas yang dipakai merupakan hasil enam kali subkultur sehingga diduga telah terjadi keragaman fenotip. Larkin (1987), melaporkan bahwa dengan melakukan subkultur yang berulang dapat meningkatkan keragaman fenotip pada tanaman.

Pola pita enzim peroksidase (Gambar 1) pada daun bibit mutan pisang Kepok didapatkan tiga pola pita. Pola pita pertama sama dengan kontrol dengan jarak migrasi relatif 20 dan 30, pola pita kedua dengan jarak migrasi relatif 15,40 dan 60 , dan pola pita tiga dengan migrasi relatif 15,35 dan 50. Dari ketiga pola pita terdapat empat buah pita dengan jarak migrasi relatif yang berbeda. Ini menunjukkan adanya penambahan keragaman isozim pada enzim peroksidase yang terbentuk sebagai akibat dari perubahan struktur/susunan rantai polipeptida yang membangun molekul protein/enzim peroksidase. Menurut Lassner dan Orton (1983), bahwa terjadinya mutasi dapat menyebabkan penyimpangan pola pita enzim. Selanjutnya Hartati dan Sukmadjaja (2002), menyatakan bahwa mutasi yang ditimbulkan akibat pemberian mutagen EMS diantaranya adalah terjadinya perpasangan yang keliru pada basa nukleotida saat replikasi DNA, dimana guanin yang seharusnya berpasangan dengan sitosin menjadi berpasangan dengan timin. Akibat kesalahan ini terjadi perubahan struktur pada susunan basa nukleotida yang juga berpengaruh terhadap sintesis enzim/proteinnya

Adanya variasi pola pita enzim yang muncul ini menunjukkan adanya polimorfik pada enzim peroksidase

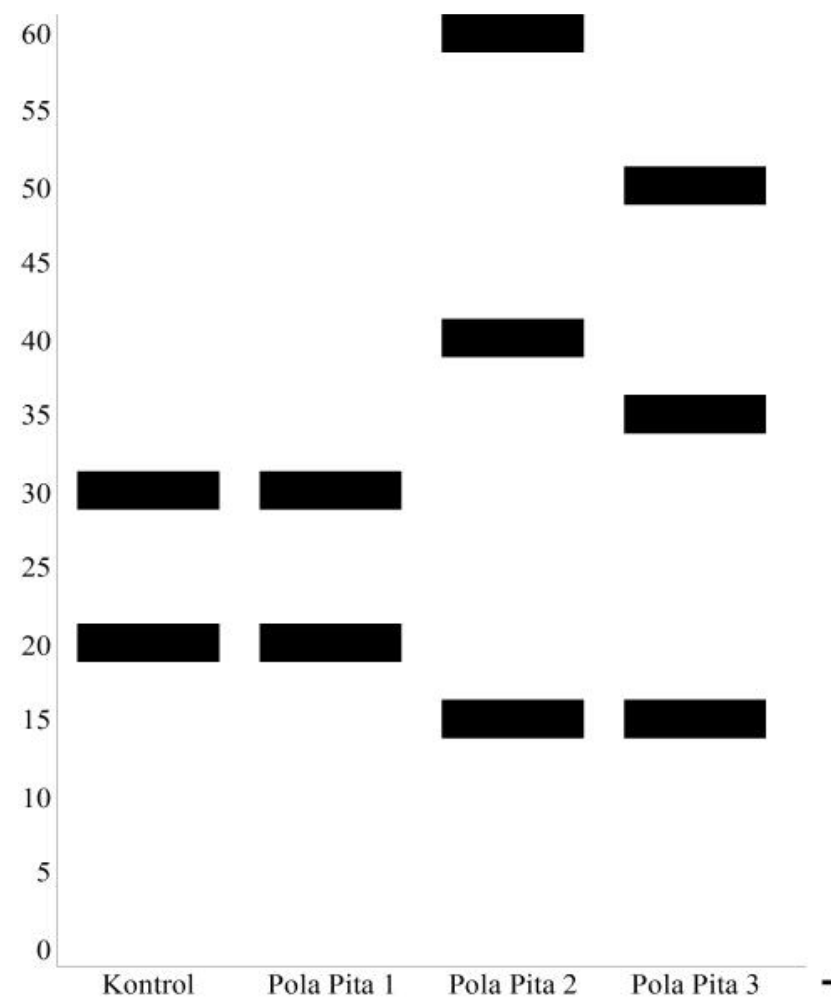

Gambar 1 Pola pita peroksidase berdasarkan zimogram

akibat dari perubahan struktur molekul polipeptida karena pemberian EMS. Menurut Novarianto (1994), bahwa terjadinya perubahan struktur molekul penyandi suatu enzim/protein dapat mengakibatkan terjadinya polimorfik enzim.

\section{SIMPULAN}

Perlakuan induksi mutasi dengan EMS secara in vitro dapat meningkatkan nilai varian dan koefisien keragaman aktivitas enzim peroksidase dengan nilai berturut-turut 8,45 dan $75,75 \%$, sedangkan pada kontrol yaitu 0,28 dan $29,92 \%$. Pola pita peroksidase pada daun bibit pisang Kepok hasil perlakuan dengan EMS secara elektroforesis terdiri atas tiga pola pita. Pola pita pertama sama dengan kontrol pada jarak migrasi relatif 20 dan 30 , pola pita kedua dengan jarak migrasi relatif 15,40 dan 60 , dan pola pita ketiga dengan jarak migrasi relatif 15, 35 dan 50. Terdapat empat pita dengan jarak migrasi relatif yang berbeda, yang menunjukkan adanya polimorfik

\section{UCAPAN TERIMA KASIH}

Pada kesempatan ini saya mengucapkan terima kasih kepada Bapak Prof. Dr. Mansyurdin, MS yang telah membantu dalam penelitian ini serta kepada Bapak Pras di PAU IPB Bogor yang membantu selama bekerja di sana. Penelitian ini dibiayai oleh Direktorat Jenderal Pendidikan Tinggi Departemen Pendidikan Nasional dengan kontrak No: 051a/H.16PL/DM/III/2007, tanggal 23 Maret 2007. 


\section{DAFTAR PUSTAKA}

Agrios, G.N. 2005. Plant Pathology. Ed ke-5. San Diego: Academic Press.

Andini, L.S, Sri, H.S., Harsojo \& Anastasia, S.D. 1993. Produks enzim amilase oleh Aspergillus oryzae iradiasi dalam substrat sagu iradiasi. Dalam: Aplikasi Isotop dan Radiasi dalam Bidang Industri, Pertanian dan Lingkungan. BATAN Jakarta .25-30.

Arisoesilaningsih, E. 1984. Resitensi dua varietas Kacang Hijau (Phaseolus radiatus L) terhadap serangan rebah kecambah oleh Rhizoctonia solani. Thesis Sarjana Biologi. Institut Teknologi Bandung.

Bateman, D.F. 1967. Increase in Peroxidase Desearsed Plant Tissue In Source Book of Laboratory Exercises In Plant Pathology. W. H. Freeman and Co. San Fransisco.

Carusso, C., Chilosi, G., Leonardi, L., Bertini, L., Magro, P., Buonocore, V. \& Caporale, C. 2001. A basic peroxidase from wheat kernel with antifungal activity. Phytochemistry 58: 743-750.

Fegan, M. \& Prior. 2005. How Complex is the "Ralstonia Solanacearum Species Complex”. Di dalam: Allen, C., Prior, P., Hayward, A.C. (Eds). Bacterial Wilt Disease and The Ralstonia solanacearum Species Complex. St. Paul. USA: APS Press.

Gaspar, T.h. 1984. Integrated Relationship of Biochemical and Physiological Peraoxidase Activities. Di dalam: H. C. Penel and Th. Gaspar (Eds). Molecular and physiologycal asspects of plant peroxidase greppin. University of Geneva Switzerland.

Hardanti, S. \& Sukmadjaja, D. 2002. Keragaman beberapa pola pita aksesi Nenas berdasarkan analisis Isozim. J. Bioteknologi Pertanian (7): 2 62-70.

Hadi, H. 2003. Analisis Genetik Sifat Ketahanan Tanaman Kare Terhadap Penyakit Gugur Daun Corynespora. Disertasi Sekolah Pasca Sarjana. Institut Pertanian Bogor.

Imelda, M., Estiati, A. \& Hartati, N.S. 2001. Induction of Mutation through Gamma Irradition in three Cultivars of Banana. J. Annalaes Bogorienses 7(2): 75-82.

Jamaluddin, S.A. 1995. Mutation breeding of banana in Malaysia, Musarama 7(1): 5 .

Kanazawa, K., Eguchi, N., Iwara, S. \& Oetomo. 1981 Electrophoretic Study On Esterase Dan Peroxidase In Stain Blackcrossed With Pollen Of Chinese Cabagge With Reference To Nucleus Substation. Di dalam: Takekar, N. and Griggs, T.D. (Eds). Chinese Cabagge. Proceedings of The First International Cabagge Symposiuim. Avrds. Taiwan 377-383.

Larkin, P.J. 1987. Somaclonal varition history. Methode and meaning. Isma State $J$. of res 61.

Lassner, M.W. \& Orton, T.J. 1983. Detection of Somatic Variation. Di dalam: Tanskley, S.D and Orton, T.J. (Eds). Isozym in plant genetics breeding. Part A. Elsevier Publishing Company Inc. Amsterdam, the Netherlands.

Michael, W., Lassner, Thomas, J. \& Orton, T.J. 1983. Detection of Somatic Variation. In: isozym in plant genetics breeding. Part A. Tanskley, S.D and Orton, T.J. (ed). elsevier publishing company inc. Amsterdam: the netherlands.

Micke, A. 1996. 70 years induced mutation to be reconsidered? mutation breeding. Newletter 42: 22-24.

Mittal, R.K., Singh, M. \& Maaherchanbdani, N. 1997. Isozym diversity index of vigna parent in relation to heterosis for seed yield in green gran (Vigna radiati) Wilczek. Euphytica 36: 61-68.

Novarianto, H. 1994. Pola pewarisan Isozim pada Tanaman Kelapa. J. Penelitian Kelapa 7(1): 30-35.

Potdukhe, N.R. 2004. Effect of Physical and chemical mutagens in M1 generation in red gram (Cajanus cajan) Nat. J. Pl. Improve 6(2): 108-111.

Rahayuningsih, S.T., Djojodirdjo, S., Hartiko, H. \& Woejono, M.D. 1989. Kajian peroksidase dan hubungan dengan sifat ketahanan tanaman lada terhadap infeksi Phytoptora palmivora. Jurnal Berkala Penelitian Pascasarjana UGM 467-471.

Ritawati, L. 2001. Polimorfisme Isoenzim beberapa tetua dan Hasil persilangan Karet serta hubungan ketahanannya terhadap Corynespora cassiicola. Thesis. Pasca Sarjana UNAND. Padang.

Saravanan, T., Bhaskaran, R. \& Muthusamy, M. 2004 Pseudomonas fluorescens Induced Enzymological Changes in Banana Roots (Cv. Rasthali) against Fusarium Wilt Disease. $J$. Plant Pathology 3(2): 72-80.

Silverio, G.L., Jhon, T.A., David, D.P., Elvira, G. \& David, J.B. 2007. Soluble peroxidase activity in maize endosperm associated with Maize Weevil Resistance. J. Crop Science Society of America 15-22.

Sussiyanti. 2000. Sifat pertumbuhan dan pola pita isozim planlet kultivar tanaman lada (Piper ningrum) pada beberapa tingkat keracunan Al secara in vitro. Thesis Pascasarjana. UNAND. Padang.

Wisnubroto, Syaifulla \& Satsijati. 1994. Hasil Penelitian Holtikultura Pelita V. Jakarta: Puslitbangtan.

Yanti, Y., Habazar, T., Mardinus \& Mansyurdin. 2008. Perubahan bentuk planlet Pisang Raja Sereh hasil mutasi dengan etie metana sulfmat (EMS) secara in Vitro. J. Natur Indonesia 12(2): 104-108.

Yuhermita. 2002. Fenotip peroksidase pada cabai keriting (Capsicum annumm) dan cabai rawit (Capsicum frutescens). Skripsi Sarjana Biologi FMIPA UNAND. Padang. 
